\title{
The Impact of Perceived Risks on the Consumer Resistance towards Generic Drugs in the Malaysia Pharmaceutical Industry
}

\author{
Anas Ahmad Abzakh ${ }^{1}$, Kwek Choon Ling ${ }^{1} \&$ Khaled Alkilani ${ }^{1}$ \\ ${ }^{1}$ Faculty of Business and Information Science, UCSI University, Kuala Lumpur, Malaysia \\ Correspondence: Kwek Choon Ling, Faculty of Business and Information Science, UCSI University. No. 1, \\ Jalan Menara Gading, UCSI Heights, 56000, Kuala Lumpur, Malaysia. Tel: 616-688-6248. E-mail: \\ kwekcl@ucsi.edu.my
}

Received: September 18, 2012

Accepted: December 7, 2012 Online Published: January 15, 2013

doi:10.5539/ijbm.v8n3p42

URL: http://dx.doi.org/10.5539/ijbm.v8n3p42

\begin{abstract}
The objective presented in this study was to evaluate the relationship between the dimensions of perceived risk (financial risk, performance risk-technology, performance risk-infrastructure, physical risk, time risk, social risk, and psychological risk) and consumer resistance towards generic drug in Malaysia. A study on consumers who resist generic drugs usage by purchasing the branded drugs over the counters was undertaken through the usage of self-administered questionnaire survey. Seven hypotheses were developed based on the proposed conceptual framework. In total, 456 branded drug users were surveyed in one of the private pharmaceutical providers that allocated in Klang Valley. Samples were drawn based on convenience sampling technique and multiple regression analysis will be used as statistical technique to empirical testing the tested hypotheses.
\end{abstract}

Keywords: perceived risk, financial risk, performance risk-technology, performance risk-infrastructure, physical risk, time risk, social risk, psychological risk, consumer resistance

\section{Introduction}

The Malaysian pharmaceutical industry is a fast growing industry that is targeted for promotion and development by the government (The Malaysian Industrial Development Authority, 2009). The Malaysian National Medicines Policy (MNMP) is a formal government document that interprets and prioritizes the medium- and long-term objectives of the national pharmaceutical policies that guide the development of pharmaceutical industry players in the country. The greater portion of this policy aims to increase the consumption of generic drugs among the health care providers and patients (Ministry of Health Malaysia, 2009).

The products that manufactured by the Malaysian pharmaceutical industry are broadly categorized into four categories, including prescription medicines, over-the-counter (OTC) products, traditional medicines and generic drug. The pharmaceutical industry in Malaysia is mainly dominated by small and medium-sized companies that engaging in the production of generic drugs, traditional medicines and herbal supplements as well as contract manufacturing for the foreign multinational corporations (The Malaysian Industrial Development Authority, 2009). Branded drug represents the majority of drug market at a share of greater than 70 percent in the country, command the greater portion in relation to value and is a main source of high drug expenditure in Malaysia. Most of the branded drugs in Malaysia are dispensed through private health care and pharmaceutical providers (Ministry of Health Malaysia, 2009). The above findings oppose the main objectives of MNMP to encourage the public towards wider usage of generic drugs in the pharmaceutical industry. Therefore, knowing the reasons that drive consumers to resist using generic drugs in Malaysia is substantial.

\section{Literature Review}

\subsection{Consumer Resistance}

The concept of consumer resistance was introduced to the social marketing literature by Penaloza and Price (1993). As the term suggests, all acts of consumer resistance must include: 'Consumer refers to a person, or person acting within, but sometimes attempting to escape, the marketing system'; and 'Resistance refers to the forms of variable oppositional responses to a practice of dominance within the market place such as commercial pressure, influence, strategies, logic or discourses that are perceived, by the consumer/person, as dissonant and antagonistic to their beliefs'. Consumer resistance is defined as consumer confronts or escapes from a dominant 
force exercised by specific actors, behaviours, and devices (Roux, 2007). Fournier (1998) asserts that consumers express their resistance in the form of continuous detrimental behaviours and actions, the oppositions ranges from less-effect behaviours such as avoiding the consumption of particular type of products to intermediate-effect behaviours like lowering the consumption and sometimes they practice more offensive behaviours like companies boycotts. The following content will evaluate the impacts of the dimensions of perceived risk (ie., financial risks, performance risk -- technology, performance risk -- infrastructure, physical risk, time risk, social risk and psychological risk) on the consumer resistance towards generic drug.

\subsection{Dimensions of Perceived Risk}

The term 'perceived risk' is primarily involved with the uncertainty caused by consumer's inability to expect the consequences of their purchase decisions (Frambach, 1993). Several researches have adopted five dimensions of perceived risk that identified by Jacoby and Kaplan (1972): Financial Risk, Performance Risk, Physical Risk, Social Risk, and Psychological Risk (Cheron and Ritchie, 1982; Mitra, Reiss and Capella, 1999; Stone and Gronhaug, 1993; Stone and Mason, 1995). At the latest study, Roselius (1971) adds one more dimension to the literature as called 'time risk'. These six dimensions mentioned above had been tested as well as evaluated toward resistance to innovation (Wiedmann et al., 2011). This study will try to reveal how these six dimensions of perceived risk relate to the consumer resistance towards generic drugs.

\subsubsection{Financial Risk}

Financial risk is sometimes referred to economic risk. Financial risk involves with the potentiality of fiscal losses caused by purchasing the products (Jacoby and Kaplan, 1972). The study from Hutton and Wilkie (1980) suggests that financial risk is defined in relation to the possible fiscal expenditure engaged with the first payment and any consequent repair expenses related with purchasing a product. In other words, financial risk contains the consumer's concerns about the amount of possible financial lose if the generic drug does not fulfill the claim as expected.

\subsubsection{Performance Risk}

The structure of performance risk is created due to the discrepancy between the product performance and consumer expectation (Pope, Brown and Forrest, 1999). This perspective drives to the notion that buying the product has a degree of risk involved. Performance risk can be considered as the concerns that the purchased product might not perform as the consumer expect and so it will not deliver the benefits as perceived (Mitchell, 1988). Performance risk can be divided into two categories: performance risk - technology and performance risk - infrastructure (Mitchell, 1988). If the products can not perform as it is expected, it is known as performance risk - technology (Wiedmann et al., 2011). If the product is not available or the outlets of selling the products are insufficient is known as performance risk - infrastructure (Wiedmann et al., 2011). Both types of performance risk toward generic drugs will be tested as determinants of the customer resistance towards generic drug in this research.

\subsubsection{Physical Risk}

Physical risk is defined as the potentiality that products or services are damaging or harmful to individuals' health (Jacoby and Kaplan, 1972) or when the product image do not seem as healthy as the consumer expect (Simpson and Lakner, 1993). Physical risk can be referred as concerns about dangers to the individuals' health and to their physical energy resulted from using generic drugs. Thus, it is wisely to investigate whether the physical risk acts as a driving force to discourage consumers to consume generic drugs in this study.

\subsubsection{Time Risk}

Performing a doubtful buying process might be a wasting-time concern for consumers throughout spending extra time related with the searching and buying, discovering the safe and correct way to consume the product, and the time required to change the product in case of poor performance or disability of the product to perform as expected (Feathermana and Pavloub, 2003; Roselius, 1971). Time risk can be involved with the wasting time by using generic drugs such as knowing the difference with branded drugs and the side-effects of using generic drugs.

\subsubsection{Social Risk}

The term 'Social risk' is described as the possible damage of status in one's social group due to purchasing or using a specific product or service, appearing wacky or not fashionable (Feathermana and Pavloub, 2003). Therefore, Jacoby and Kaplan (1972) argue that the social risk is involved with persons' view towards others according to the consumption behaviour they practice. In other words, customers may resist an innovative 
product because they feel that they will face social ostracism or peer ridicule when they adopt the innovative product. In the context of this research, there is a possibility that consumers who are using generic drugs might not be accepted by his/her society members.

\subsubsection{Psychological Risk}

Psychological risk will be created when the selection or performance of the products/services negatively affect individuals' self-perception (Mitchell, 1992). In other words, it is the possible absent of self-esteem driven from disappointment made when the product does not accomplish the purchasing objective. Stone and Gronhaug (1993) argue that the psychological risk is involved when any psychological inconvenience caused by using innovative technology due to the fact that it is common for consumers to have incomplete or inexact knowledge about this technology. In this research, consumers may face some psychological risks in related to the consumption of generic drugs due to the insufficient knowledge of the generic drugs.

\subsection{Research Gap}

Literature is well informed with the concept of consumer resistance to innovations, while there are few empirical studies on consumer resistance towards generic drug (Bredahl, 2001; Ram and Sheth, 1989; Saba, Rosati and Vassallo, 2000). In addition, the extant literature has mentioned that the dimensions of perceived risk (financial risk, performance risk, physical risk, time risk, social risk, psychological risk) have a relationship with consumer resistance to innovation (Ram and Sheth, 1989; Bredahl, 2001). Yet, the extant literature is not wealthy in term of evaluating the relationship between the dimensions of perceived risk and consumer resistance towards generic drug, especially in the health care industry. Therefore, this research would like to investigate the above relationships in the context of consumer resistance towards generic drug in the Malaysia pharmaceutical industry.

\subsection{Research Justification}

Understanding the determinants of consumer resistance towards generic drugs would be essential in supporting the efforts towards encouraging the mass usage of generic drugs in both public and private health care and pharmaceutical providers in the country. Consumers' choice to purchase generic drugs is considered as substantial indicator to measure the successfulness of implementing generic medicines substitution policy (Thomas and Vitry, 2009). Through the empirical testing the relationships between the dimensions of perceived risk and customer resistance towards generic drugs, perhaps the findings can provide insights for consumer resistance to generic drug and serve as a guideline for formulating and implementing the medicine policies more effectively and efficiently. If policy makers and executives are able to reveal, measure, or alleviate the various drivers of consumer resistance, they would achieve -directly or indirectly - the perceived goals in relation to promoting the usage of generic drugs (Ministry of Health Malaysia, 2009). Accordingly, the study results indicate that proactivity and reactivity must be exercised by drugs policy makers and government's executives in assuring the consumer involvement in the process of supporting government efforts in promoting the consumption of generic drugs. Therefore, it is interesting for researchers to find out what drives Malaysian consumers to resist generic drugs usage in which eventually would contribute to the achievement of the Malaysian National Medicine policy. In conclusion, the findings from this research will provide more insights and feedbacks for developing a fruitful generic medicines substitution policy in Malaysia (Babar and Awaisu, 2008).

\subsection{The Conceptual Framework Developed for This Research}

According to the above literature and the model used by Wiedmann et al. (2011), this conceptual framework is developed and will be tested in this research. Figure 1 represents the developed conceptual framework for this study. 


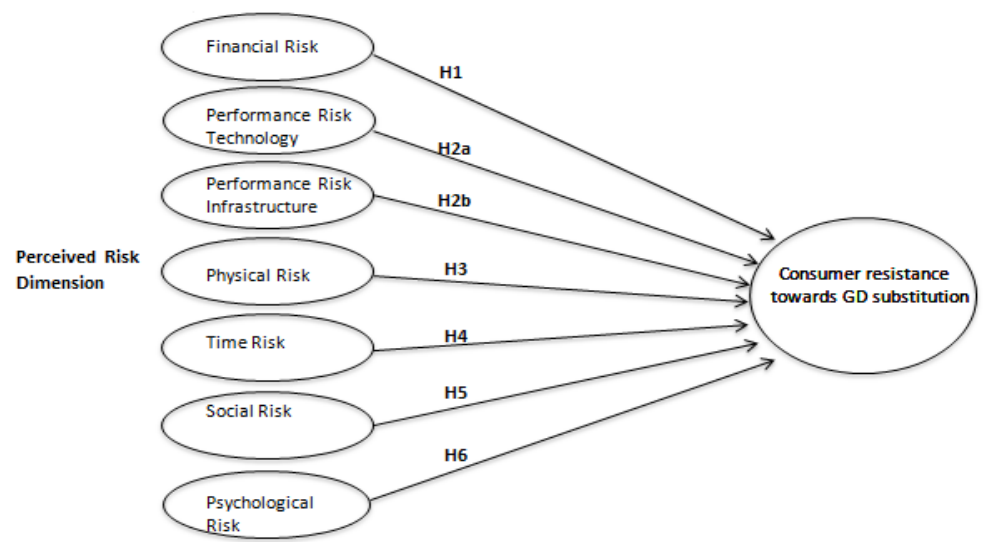

Source: Developed for this research

Figure 1. The proposed conceptual framework for this research

\subsection{Hypotheses}

The summary of investigating extant literature as well as the hypothesis developed for this study were provided in the previous discussion. Seven tested hypotheses are presented as below:

H1: Financial risk is positively related to consumer resistance towards generic drugs

H2a: Performance risk (technology) is positively related to consumer resistance towards generic drugs

$\mathrm{H} 2 \mathrm{~b}$ : Performance risk (infrastructure) is positively related to consumer resistance towards generic drugs

H3: Physical risk is positively related to consumer resistance towards generic drugs

H4: Time risk is positively related to consumer resistance towards generic drugs

H5: Social risk is positively related to consumer resistance towards generic drugs

H6: Psychological risk is positively related to consumer resistance towards generic drugs

\section{Research Design}

Adoption of descriptive research is considered in this study due to the fact that the study has clear hypotheses and richness of extant literature (Malhotra, 2006). Primary data will be collected through self-administered survey based on a cross-sectional study.

\subsection{Questionnaire Design}

The adopted questionnaire used in this research can be divided into two parts. Part A will illustrate the respondents' demographic profiles, such as gender, age and marital status. Part B will present all the variables that used to elaborate various tested constructs in this research. Measuring the constructs adapted in this study will be accomplished by 3 items for 'Financial risk', 'Performance risk (technology)', 'Performance risk (infrastructure)', 'Physical risk', 'Psychological risk' and 'Consumer resistance towards generic drugs' respectively and all the items are adapted from Wiedmann et al. (2011). Both the constructs of 'time risk' and 'social risk' are measured by 2 items respectively and sourced from Wiedmann et al. (2011). All the tested constructs in the proposed conceptual framework will be measured by Likert Scale using 5-point scale, ranging from number 1 (represents strongly disagree to number 5 (represents strongly agree).

\subsection{Sampling Design}

All the walked in customers who refuse to buy the generic drugs over the counter in one of the private pharmaceutical providers that allocated in Klang Valley will be targeted as the potential respondents in this research. Convenience sampling technique is adopted in this study due to the lacking of sampling frame. A pilot test will be performed prior to the full scale of survey is being conducted. The questionnaire instrument was used in this survey and was disseminated to 500 respondents. Descriptive analysis, scale measurement (both reliability and validity tests) and inferential analysis (multiple regression analysis) were performed in the data analysis. 


\section{Research Results}

\subsection{Respondents' Demographic Profile}

The questionnaires used in this survey were collected in a sum of 456 sets being analyzed in the study. According to the results of respondents' demographic analysis, the percentage of respondents' gender was distributed in $54 \%$ that represents males, and $46 \%$ represents females. The age distribution of respondents were classified into six ranges: $10.7 \%$ (at the age of 12 to 20 years), $44.1 \%$ (at the age of 21 to 29 years old), $27.4 \%$ (at the age of 30 to 38 years old), 9.2\% (at the age of 39 to 47 years old), $5.7 \%$ (at the age of 48 to 56 years old), and $2.9 \%$ (above the 56 years old). Marital status of the respondents was covered in this study, $43.6 \%$ of the respondents were singles, $31.8 \%$ are parents without children, and $24.6 \%$ are parents with children.

\subsection{Reliability Test}

The reliability test is a common approach used to assist in evaluating the measures' steadiness and consistency (Cavana et al., 2001). According to Malhotra (1996), the coefficient alpha is a popular process to measure the construct's reliability; therefore it will be used in the analysis. Generally, the reliability is accepted and good when the value of coefficient alpha or Cronbach's alpha with a range of more than 0.70 (Cavana et al., 2001). Table 1 shows that the values of Cronbach's alpha for each construct used in this research, the range of values resulted extends from 0.753 referring to Performance Risk - technology (the lowest) to 0.877 referring to Financial Risk (the highest). The result indicates the stability of measurement scales to measure the construct.

Table 1. Factors identified by the principal components factor analysis

\begin{tabular}{|c|c|c|c|c|c|}
\hline Factor's Name & Variable & $\begin{array}{l}\text { Factor } \\
\text { Loading }\end{array}$ & $\begin{array}{l}\text { Eigen } \\
\text {-value }\end{array}$ & $\begin{array}{l}\text { Percentage } \\
\text { of Variance } \\
\text { Explained }\end{array}$ & $\begin{array}{c}\text { Cronbach } \\
\text { Reliability } \\
\text { Coefficients }\end{array}$ \\
\hline \multirow[t]{3}{*}{ Financial risk } & $\begin{array}{l}\text { I would be concerned that buying generic drugs } \\
\text { would not be wise. }\end{array}$ & 0.902 & 4.894 & 2.453 & 0.877 \\
\hline & $\begin{array}{l}\text { I can spend my money in a better way rather than } \\
\text { buying generic drugs. }\end{array}$ & 0.893 & & & \\
\hline & $\begin{array}{l}\text { I would be concerned that I would not get my } \\
\text { money's worth from the generic drugs. }\end{array}$ & 0.860 & & & \\
\hline \multirow[t]{3}{*}{$\begin{array}{l}\text { Physiological } \\
\text { risk }\end{array}$} & $\begin{array}{l}\text { The thought of purchasing generic drugs causes } \\
\text { me to experience unnecessary tension. }\end{array}$ & 0.881 & 2.796 & 2.402 & 0.862 \\
\hline & $\begin{array}{l}\text { The thought of purchasing generic drugs makes } \\
\text { me feel psychologically uncomfortable. }\end{array}$ & 0.850 & & & \\
\hline & $\begin{array}{l}\text { The thought of purchasing generic drugs makes } \\
\text { me feel worried. }\end{array}$ & 0.831 & & & \\
\hline $\begin{array}{l}\text { Performance } \\
\quad \text { risk }\end{array}$ & $\begin{array}{l}\text { I would not know where I should purchase generic } \\
\text { drugs. }\end{array}$ & 0.872 & 2.091 & 2.389 & 0.864 \\
\hline \multirow[t]{2}{*}{ (infrastructure) } & $\begin{array}{l}\text { The number of available pharmacies, clinics, etc. } \\
\text { for selling generic drugs is not satisfying. }\end{array}$ & 0.871 & & & \\
\hline & $\begin{array}{l}\text { On my journeys, I would have the anxiety that I } \\
\text { may not comfortably reach the pharmacies, } \\
\text { clinics, etc. where I can purchase generic drugs. }\end{array}$ & 0.854 & & & \\
\hline $\begin{array}{l}\text { Consumer } \\
\text { resistance }\end{array}$ & $\begin{array}{l}\text { I would be making a mistake by purchasing } \\
\text { generic drugs. }\end{array}$ & 0.873 & 1.734 & 2.379 & 0.862 \\
\hline \multirow[t]{2}{*}{$\begin{array}{l}\text { towards generic } \\
\text { drugs }\end{array}$} & $\begin{array}{l}\text { In the near future, the purchase of generic drugs } \\
\text { would be connected with too many uncertainties. }\end{array}$ & 0.866 & & & \\
\hline & $\begin{array}{l}\text { In sum, a possible purchase of an (delete) generic } \\
\text { drugs would cause problems that I don't need. }\end{array}$ & 0.860 & & & \\
\hline \multirow[t]{3}{*}{ Physical risk } & $\begin{array}{l}\text { One concern I have about purchasing a generic } \\
\text { drugs is that the risk of endangering my health } \\
\text { might be high. }\end{array}$ & 0.872 & 1.686 & 2.180 & 0.801 \\
\hline & $\begin{array}{l}\text { I am concerned about potential physical risks } \\
\text { associated with the consumption of generic drugs. }\end{array}$ & 0.812 & & & \\
\hline & $\begin{array}{l}\text { I have confidence concerns in the case of } \\
\text { consuming generic drugs. }\end{array}$ & 0.777 & & & \\
\hline
\end{tabular}




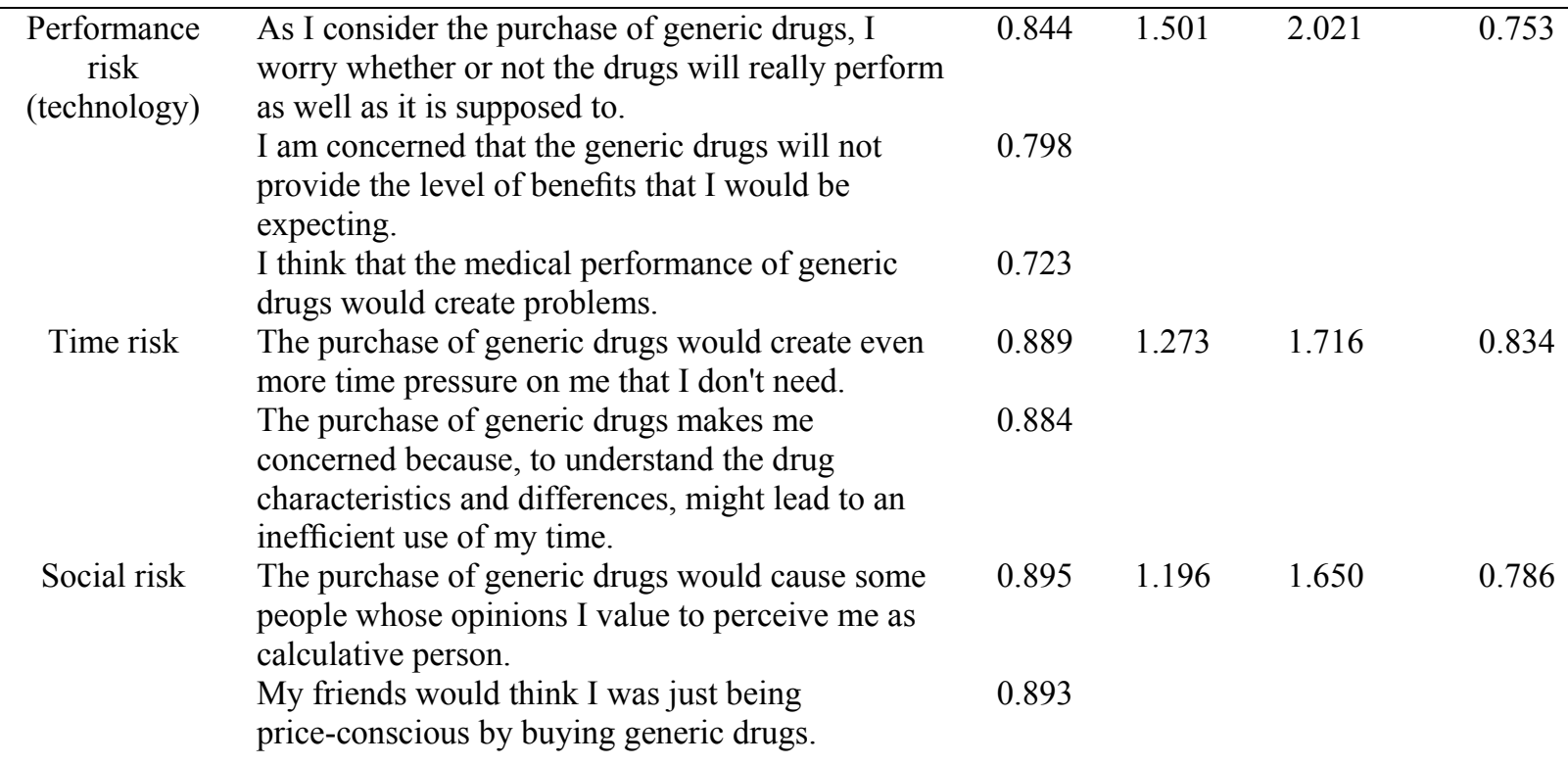

Source: Developed for this research

Note: KMO Measure of Sampling Adequacy=0.774; $\mathrm{p}=0.0001(\mathrm{p}<0.05) ; \mathrm{df}=231$, Approx. Chi-Square 4544.457; Cumulative Percentage Rotation Sums of Squared Loadings $=78.055$

\subsection{Validity Test}

Theoretically, several approaches were used in the research literature to evaluate validity of scale. In this research, the construct validity was adopted and factor analysis was used to measure the construct validity (Cavana et al., 2001). The outcome of factor analysis as illustrated in Table 1 shows that the appropriateness of the analysis being explained by the value of Kaiser-Meyer-Olkin (KMO) 0.774 (Between 0.5 and 1.0) and the analysis results for Bartlett test of sphericity was significant $(\mathrm{p}=0.000 ; \mathrm{df}=231$; approx. Chi-Square $=4544.457$ ) for each correlation within a correlational matrix (significant for several constructs adapted at least).

According to the principal components analysis and VARIMAX procedure in orthogonal rotation that were adopted in the factor analysis, the Table 1 showed the analysis results of Eigenvalues for all the examined constructs exceeded 1.0, at a range between 1.196 "Performance Risk - technology" (the lowest) to 4.894 "Financial Risk"(the highest). Concerning the convergent validity, the factor loadings were greater than 0.50 for every item used in the constructs. According to Table 1, discriminant validity was examined and the results showed that every item was assigned in consonance with the relevant construct. Accordingly, constructs overlapping was absent and the items supported the relevant constructs.

\subsection{Regression Analyses}

\subsubsection{Multiple Regression Analysis}

The technique "Multiple regression analysis" is sufficient to analyze the linear relationship among the variables, by testing the relations of one or more dependent variable and multiple independent variables; multiple regression analysis estimates the coefficients for the equation for a straight line (Hair et al., 2006). Accordingly, multiple regression analysis will be carried out in this research to test the seven developed hypotheses (H1, H2a, $\mathrm{H} 2 \mathrm{~b}, \mathrm{H} 3, \mathrm{H} 4, \mathrm{H} 5$, and H6) in this study.

According to the results showed in Table 2, the Tolerance Value was ranged between 0.921 to 0.770 in which were all more than 0.10 and the VIF value ranges from 1.086 to 1.298 in which are (were) all less than 5 (Hair et al., 2006). The findings show that there is no multicollinearity problem among all the independent variables in this research. According to Table 2, the p-value for the two independent variables (performance risk-technology and physical risk) is less than 0.05 , in which the result indicates a significant relationship towards consumer resistance. The p-value in Table 2(a) was greater than 0.05 for all the other independent variables; financial risk, performance risk-infrastructure, time risk, social risk, and psychological risk which show no significant relationship towards consumer resistance. The analysis results showed the changes of the construct 'consumer resistance' can be explained 13.5 percent ( $\mathrm{r}$ square $=13.5$ percent) by incorporation of all the independent variables in this research. 
Table 2. Result of multiple linear regression analysis

\begin{tabular}{|c|c|c|c|c|c|c|c|}
\hline \multirow{3}{*}{ Model } & \multicolumn{3}{|c|}{ Coefficients $^{\mathrm{a}}$} & \multirow{3}{*}{$\mathrm{t}$} & \multirow{3}{*}{ Sig. } & \multirow{2}{*}{\multicolumn{2}{|c|}{$\begin{array}{l}\text { Collinearity } \\
\text { Statistics }\end{array}$}} \\
\hline & \multicolumn{2}{|c|}{$\begin{array}{l}\text { Unstandardized } \\
\text { Coefficients }\end{array}$} & \multirow{2}{*}{$\begin{array}{c}\text { Standardized } \\
\text { Coefficients } \\
\text { Beta }\end{array}$} & & & & \\
\hline & $\mathrm{B}$ & Std. Error & & & & Tolerance & VIF \\
\hline (Constant) & 4.146 & .928 & & 4.468 & .000 & & \\
\hline Financial Risk & .053 & .042 & .058 & 1.267 & .206 & .921 & 1.086 \\
\hline $\begin{array}{l}\text { Performance Risk } \\
---(\text { Technology) }\end{array}$ & .232 & .065 & .173 & 3.542 & .000 & .813 & 1.231 \\
\hline $\begin{array}{l}\text { Performance Risk } \\
\text {---(Infrastructure) }\end{array}$ & .016 & .045 & .017 & .349 & .727 & .852 & 1.174 \\
\hline Physical Risk & .255 & .056 & .214 & 4.538 & .000 & .865 & 1.156 \\
\hline Time Risk & -.017 & .059 & -.014 & -.293 & .770 & .807 & 1.239 \\
\hline Social Risk & .088 & .069 & .058 & 1.272 & .204 & .925 & 1.081 \\
\hline Psychological Risk & .039 & .042 & .047 & .935 & .350 & .770 & 1.298 \\
\hline
\end{tabular}

a. Dependent Variable: Consumer resistance towards generic drugs.

b. Independent variables: Financial risk, Performance risk-technology, Performance risk-infrastructure, Physical risk, Time risk, Social risk, Psychological risk.

$R=36.7$ per cent; $R$ Square $=13.5$ per cent; Adjusted $R$ Square $=12.1$ per cent; $F=9.970 ; P=0.000(p<0.05)$

Source: Develop for this research

\section{Conclusion}

\subsection{Conclusion of Hypotheses}

The findings of this research showed in Table 3 indicate that only two independent variables (performance risk-technology and physical risk) are in positive relationship with consumer resistance towards generic drug. On the other hand, financial risk, performance risk-infrastructure, time risk, social risk, and psychological risk do not have significant relationships with the consumer resistance towards generic drugs.

Table 3. Conclusion of the seven hypotheses and the respective findings

\begin{tabular}{|c|c|c|c|}
\hline Hypothesis & Statistical test & $\begin{array}{c}\text { P-value } \\
(\mathrm{P}<0.05=\text { sig })\end{array}$ & Outcome \\
\hline $\begin{array}{l}\text { H1: Financial risk is positively related to consumer resistance towards } \\
\text { generic drugs }\end{array}$ & $\begin{array}{l}\text { Multiple linear } \\
\text { regression }\end{array}$ & 0.206 & rejected \\
\hline $\begin{array}{l}\mathrm{H} 2 \mathrm{a} \text { : Performance risk (technology) is positively related to consumer } \\
\text { resistance towards generic drugs }\end{array}$ & $\begin{array}{l}\text { Multiple linear } \\
\text { regression }\end{array}$ & 0.000 & accepted \\
\hline $\begin{array}{l}\mathrm{H} 2 \mathrm{~b} \text { : Performance risk (infrastructure) is positively related to consumer } \\
\text { resistance towards generic drugs }\end{array}$ & $\begin{array}{l}\text { Multiple linear } \\
\text { regression }\end{array}$ & 0.727 & rejected \\
\hline $\begin{array}{l}\text { H3: Physical risk is positively related to consumer resistance towards } \\
\text { generic drugs }\end{array}$ & $\begin{array}{l}\text { Multiple linear } \\
\text { regression }\end{array}$ & .000 & accepted \\
\hline $\begin{array}{l}\text { H4: Time risk is positively related to consumer resistance towards } \\
\text { generic drugs }\end{array}$ & $\begin{array}{l}\text { Multiple linear } \\
\text { regression }\end{array}$ & 0.770 & rejected \\
\hline $\begin{array}{l}\text { H5: Social risk is positively related to consumer resistance towards } \\
\text { generic drugs }\end{array}$ & $\begin{array}{l}\text { Multiple linear } \\
\text { regression }\end{array}$ & 0.204 & rejected \\
\hline $\begin{array}{l}\text { H6: Psychological risk is positively related to consumer resistance } \\
\text { towards generic drugs }\end{array}$ & $\begin{array}{l}\text { Multiple linear } \\
\text { regression }\end{array}$ & 0.350 & rejected \\
\hline
\end{tabular}

Source: Develop for this research 


\subsection{Implications of Research Findings}

This research finding does provide some insights and feedbacks for the pharmaceutical industry and Malaysian National Medicine policy makers to gain further understanding of why consumers resist generic drugs. Uncovering and measuring the reasons of consumer resistance is very helpful to policy makers in order to effectively accomplish their desirable goals in promoting the generic drug usage in the pharmaceutical industry. Accordingly, this research suggests that drug policy makers and executives must be acting in advance to address the current condition of generic drugs usage before it grows to be a wider consumer resistance problem. Thus, developing a fruitful generic medicines substitution policy in Malaysia by involving consumers in generic drugs usage is strongly encouraged.

\subsection{Research Limitations}

Besides providing some fruitful insights to the researchers in the context of consumer resistance, certain limitations need to be considered in this study that may affect its contributions. This study adopted convenience sampling method and thus the result could not be generalizable. The primary data in this study were collected through self-administered survey based on a cross-sectional study, and subsequently, the changes of consumer resistance towards generic drugs over different period of time can not be described in this study

\subsection{Research Recommendations}

The limitations of this study have derived some recommendations to future research. Investigating the respondents from rural areas was not covered in this research, therefore, the study on rural society respondents' behaviours towards generic drugs is recommended. Probability sampling technique should be recommended for the future research. Describing the changes in patterns of consumer resistance towards generic drugs might not be noted by conducting cross-sectional study. In due respect, longitudinal study to test the perceived risk and its relationship with consumer resistance towards generic drugs is recommended.

\section{References}

Babar, Z. U., \& Awaisu, A. (2008). Evaluating community pharmacists' perceptions and practices on generic medicines: A pilot study from Peninsular Malaysia. Journal of Generic Medicines, 5(4), 315-330. http://dx.doi.org/10.1057/jgm.2008.10

Bredahl, L. (2001). Determinants of consumer attitudes and purchase intentions with regard to genetically modified food - Results of a cross-national survey. Journal of Consumer Policy, 24(1), 23-61. http://dx.doi.org/10.1023/A:1010950406128

Cavana, R. Y., Delahaye, B. L., \& Sekaran, U. (2001). Applied business research: Qualitative and quantitative methods. Queensland: John Wiley \& Sons.

Cheron, E., \& Ritchie, B. (1982). Leisure activities and perceived risk. Journal of Leisure Research, 14(2), 139-154.

Feathermana, M. S., \& Pavloub, P. A. (2003). Predicting e-services adoption: A perceived risk facets perspective. International Journal of Human-Computer Studies, 59(4), 451-474. http://dx.doi.org/10.1016/S1071-5819(03)00111-3

Fournier, S. (1998). Consumers and their brands: Developing relationship theory in consumer research. Journal of Consumer Research, 24(4), 343-373. http://dx.doi.org/10.1086/209515

Frambach, R. T. (1993). An integrated model of organizational adoption and diffusion of innovations. European Journal of Marketing, 27(5), 22-41. http://dx.doi.org/10.1108/03090569310039705

Hair, J. F. J., Black, W.C., Babin, B. J., Anderson, R. E., \& Tatham, R. L. (2006). Multivariate data analysis. Pearson Education: New Jersey.

Hutton, B., \& Wilkie, W. L. (1980). Life Cycle Cost: A New Form of Consumer Information. Journal of Consumer Research, 6(4), 349-360. http://dx.doi.org/10.1086/208778

Jacoby, J., \& Kaplan, L. B. (1972). The components of perceived risk. Annual Conference of the Association for Consumer Research, 382-393.

Malhotra, N. K., \& Peterson, M. (1996). Basic marketing research: A decision-making approach ( $2^{\text {nd }}$ Eds.). New Jersey: Prentice Hall.

Malhotra, N., Hall, J., Shaw, M., \& Oppenheim, P. (2006). Marketing research: An applied orientation (3 ${ }^{\text {rd }}$ Eds.). NSW, Australia: Pearson. 
Ministry of Health Malaysia. (2009). Malaysian National Medicines Policy. Ministry of Health Malaysia. Retrieved from http://www.pharmacy.gov.my/aeimages//File/MNMP_DUNAS.pdf

Mitchell, V. W. (1988). A role for consumer risk perceptions in grocery retailing. British Food Journal, 100(4), $17-183$.

Mitchell, V. W. (1992). Organizational homoeostasis: A role for internal marketing. Journal of Management History, 30(2), 26-31.

Mitra, K., Reiss, M. C., \& Capella, L. M. (1999). An examination of perceived risk, information search and behavioral intentions in search, experience and credence services. Journal of Services Marketing, 13(3), 208-228. http://dx.doi.org/10.1108/08876049910273763

Penaloza, L., \& Price, L. (1993). Consumer resistance: A conceptual overview. Advances in Consumer Research, 20, 123-128.

Pope, N., Brown, M., \& Forrest, E. (1999). Risk, innovativeness, gender, and involvement factors affecting the intention to purchase sport product online. Sport Marketing Quarterly, 8(2), 25-34.

Ram, S., \& Sheth, J. N. (1989). Consumer resistance to innovations: The marketing problem and its solutions. The Journal of Product Innovation Management, 6(4), 298-299. http://dx.doi.org/10.1016/0737-6782(89)90083-0

Roselius, T. (1971). Consumer rankings of risk reduction methods. Journal of Marketing, 35(1), 56-61. http://dx.doi.org/10.2307/1250565

Roux, D. (2007). Consumer resistance: Proposal for an integrative framework. Rechercheet Applications en Marketing, 22(4), 59-79.

Saba, A., Rosati, S., \& Vassallo, M. (2000). Biotechnology in agriculture: Perceived risks, benefits and attitudes in Italy. British Food Journal, 102(2), 114-122. http://dx.doi.org/10.1108/00070700010313143

Simpson, L., \& Lakner, H. B. (1993). Perceived risk and mail order shopping for apparel. Journal of Consumer Studies \& Home Economics, 17(4), 377-398. http://dx.doi.org/10.1111/j.1470-6431.1993.tb00180.x

Stone, R. N., \& Grønhaug, K. (1993). Perceived Risk: Further Considerations for the Marketing Discipline. European Journal of Marketing, 27(3), 39-50. http://dx.doi.org/10.1108/03090569310026637

Stone, R. N., \& Mason, J. B. (1995). Attitude and risk: Exploring the relationship. Psychology \& Marketing, 12(2), 135-153. http://dx.doi.org/10.1002/mar.4220120205

The Malaysian Industrial Development Authority. (2009). Guide on the pharmaceutical industry in Malaysia. The Malaysian Industrial Development Authority. Retrieved from http://www.mida.gov.my/env3/uploads/

Thomas, R., \& Vitry, A. (2009). Consumers' perception of generic medicines in community pharmacies in Malaysia. LevendeTalen Magazine, 2(2), 20-23.

Wiedmann, K. P., Hennigs, N., Pankalla, L., Kassubek, M., \& Seegebarth, B. (2011). Adoption barriers and resistance to sustainable solutions in the automotive sector. Journal of Business Research, 64(11), 1201-1206. 